(RESEARCH ARTICLE)

\title{
Comparative analysis of potentially toxic elements in the soils and some vegetables collected from wastewater and river water irrigated areas in Kano city and Bichi town, Kano state, Nigeria
}

\author{
Mahadi Garba Doka ${ }^{1}$, Nura Tasiu 1, Isaac Aloba ${ }^{1}$, Shamsu Ishaq Abdullahi ${ }^{2}$ and Datti Yau 3,* \\ ${ }^{1}$ Department of Chemistry, Federal College of Education (Technical) Bichi, Kano. \\ ${ }^{2}$ Department of Biology, Federal College of Education (Technical) Bichi, Kano. \\ ${ }^{3}$ Department of Chemistry, Yusuf Maitama Sule University, Kano.
}

Publication history: Received on 20 July 2020; revised on 09 August 2020; accepted on 11 August 2020

Article DOI: https://doi.org/10.30574/wjarr.2020.7.2.0270

\begin{abstract}
Urban vegetables farming using untreated wastewater is raising a serious health concern associated with consumption of these vegetables. The potentially toxic elements (PTEs) contents in six selected vegetable samples and their soils from Kano City and Bichi town were evaluated by using atomic absorption spectrophotometer. The concentrations of these metals in both Kano City and Bichi town soils were respectively found to be: Cd $(0.001 \pm 0.001$ to $0.023 \pm 0.001$ and ND); Co (ND to $0.322 \pm 0.004$ and ND to $1.485 \pm 0.001$ ); $\mathrm{Cr}$ (ND to $0.080 \pm 0.000$ and $0.01 \pm 0.00$ to $0.083 \pm 0.005$ ); $\mathrm{Mn}$ $(0.043 \pm 0.015$ to $34.746 \pm 0.011$ and ND to $25.00 \pm 0.000) ; \mathrm{Ni}(0.723 \pm 0.011$ to $2.8467 \pm 0.231$ and $1.234 \pm 0.000$ to 6.542 \pm 0.038$) ; \mathrm{Pb}(2.202 \pm 0.001$ to $20.42 \pm 0.100$ and $1.413 \pm 0.001$ to $15.570 \pm 0.005)$. While the concentrations of these metals in both Kano City and Bichi town vegetables were respectively found to be: $\mathrm{Cd}(0.007 \pm 0.001$ to $0.063 \pm 0.001$ and $\mathrm{ND}$ ); Co (ND to $0.133 \pm 0.003$ and ND to $0.165 \pm 0.001)$; $\mathrm{Cr}(0.002 \pm 0.001$ to $0.140 \pm 0.010$ and $0.035 \pm 0.010$ to $0.880 \pm 0.010)$; $\mathrm{Mn}(2.206 \pm 0.002$ to $15.250 \pm 0.051$ and $0.198 \pm 0.000$ to $11.494 \pm 0.041)$; Ni $(0.423 \pm 0.002$ to $5.161 \pm 0.002$ and $0.928 \pm 0.002$ to $2.837 \pm 0.003)$; $\mathrm{Pb}(2.478 \pm 0.051$ to $13.723 \pm 0.552$ and ND to $9.668 \pm 0.007)$. The results showed that the concentrations of some PTEs in the analyzed samples are all below the WHO permissible limits, while in some the concentrations are above the WHO permissible limit.
\end{abstract}

Keywords: PTEs; Atomic Absorption Spectrophotometer; CPI; Kano City; Bichi town

\section{Introduction}

Human activities such as industrial production, mining, agriculture and transportation release high amount of toxic metals into surface water, soils and ultimately to the biosphere. Accumulation of toxic elements in crop plant is of great concern due to the probability of food contamination through the soil-root interface [1]. Though heavy metals like cadmium, lead, Nickel are not essential for plant growth, they are readily taken up and accumulated by plants in potentially toxic forms. Ingestion of vegetables irrigated with wastewater and grown in soil contaminated with toxic metals possesses a possible risk to human health and wildlife [2]. Heavy metal concentration in the soil solution plays an important role in controlling metal bioavailability to plants [3]. Most of the studies show that the use of wastewater contaminated with heavy metals for irrigation over long period of time increases the heavy metal content of soils above permissible limit. Ultimately, increasing the heavy metal contents in soil also increases the uptake of heavy metals by plants depending on the soil type, plant growth stages and plant species [4].

Vegetables constitute an important part of the human diet, containing carbohydrates and proteins, as well as vitamins, minerals and trace elements [5]. In recent years their consumption is gradually increasing, particularly among the urban communities, and this is due to the increased awareness on the food value of vegetables [6]. However, vegetables may contain both essential and toxic elements over a wide range of concentrations, with their accumulations posing a direct

\footnotetext{
* Corresponding author: Datti Yau
} 
threat to human health [7]. Heavy metals such as cadmium, copper, lead, chromium and mercury, are important environmental pollutants, particularly in areas irrigated with wastewater. Heavy metals are the most important contaminants that can be found on the surface and in the tissue of fresh vegetables [8]. Earlier studies by Ewers [9] and Kabata-Pendias [10] as quoted by Lacatusu [11] and reported by Ekwue et al., [12] were aimed at interpreting the levels of soil heavy metals. However, the standards employed for interpreting soil heavy metals pollution/contamination vary from country to country based on chosen factors [11].

In this research work, similar comparison of heavy metals load in vegetables and soils irrigated with wastewater and river water was made using the method adopted by Lacatusu [11] in measuring the concentrations of heavy metals in the vegetables and soil using Atomic Absorption spectrophotometer (model 240FSAA, 200 Series Agilent Technology).

\section{Material and methods}

\subsection{The Study Areas}

Kano City is in the center of Kano State (Latitude. $12^{\circ} 02 \mathrm{~N}$, Longitude $08^{\circ} 30 \mathrm{E}$ ) in Northern Nigeria. Kano State is the most populous state in Nigeria. The population of Kano City is estimated at over 3 million according to the 2006 national population census report. Kano State is the commercial nerve center of Northern Nigeria. The high population is brought about by a lot of economic and industrial activities taking place in the city. Kano City is located on the main watershed, which separates the two main river basins in the metropolis. The Jakara River basin in the North and the Kano river basin lay to the south of the water divide. The basin is being drained by two major rivers: Kano River and Challawa River [13].

Bichi Local Government Area is hosted by Kano state, the most populous state in Nigeria. Bichi bears almost similar geographical description with Kano City $[13,14]$.

In Kano City, the gardens of Zungeru-Kwaciri and Zungeru-Gayawa-Dankunkuru were evenly distributed across this stretch, and usually used different wastewater from Jakara dendritic types of drainage basin which carries all domestic and industrial wastewater comprises of over 200 hundred industries ranging from tanneries, rubber and plastic industries, textiles metal smelting industries and abattoirs all discharge their untreated wastewater into the JakaraKwaciri-Gama-Gayawa water streams. While in Bichi dry seasons farms distributed on the bank of Bagwai dam. Vegetables such as cabbage (Brassica oleracea), lettuce (Lactuca sativa), okra (Hibiscus esculentus)) spinach (Amaranthus hybridus) pepper (capsicum) and watermelon (Citrullus lanatus) are cultivated in this low laying areas which are believe to be fertile and source of water though, they may be reach in heavy metals.

\subsection{Sampling}

Ten farms were randomly selected, five (5) from Kano City along Zungeru-Gayawa-Dankunkuru dry seasons farms, and five (5) from Bichi Local Government along Bagwai dam dry season irrigation farms [13]. A total of six vegetables were randomly selected within 2-3 hectares of dry season farms in Kano City and Bichi town, between the month of October and November 2019. All the samples were collected in triplicate.

The entire vegetables samples were uprooted from a point and their respective soils were collected. The soil samples were collected within the depth of 0-15, 20-25, and 30-45 cm depths.

\subsection{Chemical Analysis}

All the samples were washed, air-dried for one week; oven dried at $65^{\circ} \mathrm{C}$ for 24 hours, and then digested using the procedure reported by Nafiu and Aisha [15] with slight modification.

The soil samples were dried at $40^{\circ} \mathrm{C}$ for $48 \mathrm{hr}$ in hot air oven and crushed and passed through a $2 \mathrm{~mm}$ nylon sieve. A diacid mixture was used. A measured amount ( $5 \mathrm{~g}$ ) of the soil sample was then transferred into $100 \mathrm{ml}$ beaker to which $25 \mathrm{ml}$ of concentrated $\mathrm{HNO}_{3}$ and $5 \mathrm{ml}$ of perchloric acid were added in the ratio of 5:1. The mixture was placed on a hot plate at $105^{\circ} \mathrm{C}$ for one hour and then temperature was increased to $140^{\circ} \mathrm{C}$ until the sample completely dried. After cooling, the solution was mixed and filtered through Whatman No. 42 filter paper into a 50 ml volumetric flask, and made up to $50 \mathrm{ml}$ with distilled water. Digested samples were then analyzed using Atomic Absorption spectrophotometer according to the AOAC [16] procedure as adopted and modified by Babandi et al., [13] Okalebo and Gathua [17]; Anthony and Balwant [18]. 
Digestion of the vegetables samples was done using a di-acid mixture $\left(\mathrm{HNO}_{3}\right.$ and $\mathrm{HClO}_{4}$ in the ratio $\left.3: 1\right)$. Here $5 \mathrm{ml}$ of concentrated $\mathrm{HNO}_{3}$ was added to $1 \mathrm{~g}$ of the plant material and kept overnight. Then $12 \mathrm{ml}$ of the diacid mixture was added and digested on hot plate until white reddish brown fumes of perchloric acid appeared. After a few hours, the plant sample completely dissolved in the digestion mixture and the solution was evaporated until about $2 \mathrm{ml}$ was left in the flask. These digested samples were then transferred into digestion bottles for analysis using Atomic Absorption spectrophotometer according to the AOAC [16] procedure as adopted and modified by Babandi et al., [13] Emmanuel and Nurudeen [14]; Okalebo and Gathua [17]; Anthony and Balwant [18].

\subsection{Quality Control Analysis}

All the chemicals used were of analytical grade.

Double deionized water was used for solution preparation and glassware was washed with $10 \% \mathrm{HNO}_{3}$. Standards were prepared for each metal from their stock solution to calibrate the instrument. Precision and accuracy of analysis were checked through repeated analysis [13].

\subsection{Statistical Analysis}

The data were statistically analyzed by SPSS software version 16.0. All analyses were performed in triplicates. Results were expressed by means of \pm SD. Statistical significance was established using one way analysis of variance (ANOVA). Means were separated according to Duncan's multiple range analysis $(\mathrm{p}<0.05)$.

\section{Results and discussion}

The results for the mean concentration of heavy metals in Kano soils are presented in Table 1.0, while that of the mean concentration of heavy metals in Kano vegetables leaves are presented in Table 2.0. Similarly, the results for mean concentration of heavy metals of Bichi Soils are presented in Table 3.0, while that of the mean concentration of heavy metals of Bichi vegetables leaves are presented in Table 4.0. Table 5.0 shows the World Health Organization maximum permissible standard. Table 6.0 gives the significance of pollution indices of heavy metals in vegetables of different farms in Kano, while Table 7.0 gives the significance of pollution indices of heavy metals in vegetables of different farms in Bichi. Table 8.0 shows the significance of intervals of Contamination/Pollution Index (CPI) standard.

Table 1 Mean Concentration of Heavy Metals in Kano Soils

\begin{tabular}{llllllll}
\hline Area & Metals & CSK & LSK & OSK & WSK & SSK & PSK \\
& $\mathbf{m g} /$ Kg & Mean \pm SD & Mean \pm SD & Mean \pm SD & Mean \pm SD & Mean \pm SD & Mean \pm SD \\
\hline Kano & $\mathrm{Cd}$ & $0.007 \pm 0.001$ & $0.001 \pm 0.001$ & $0.014 \pm 0.001$ & $0.009 \pm 0.00$ & $0.023 \pm 0.001$ & $0.005 \pm 0.000$ \\
& $\mathrm{Co}$ & $\mathrm{ND}$ & $0.322 \pm 0.004$ & $\mathrm{ND}$ & $\mathrm{ND}$ & $\mathrm{ND}$ & $\mathrm{ND}$ \\
& $\mathrm{Cr}$ & $0.050 \pm 0.010$ & $\mathrm{ND}$ & $0.080 \pm 0.000$ & $0.050 \pm 0.01$ & $\mathrm{ND}$ & $\mathrm{ND}$ \\
& $\mathrm{Mn}$ & $34.746 \pm 0.011$ & $10.382 \pm 0.146$ & $3.323 \pm 0.103$ & $21.77 \pm 0.02$ & $15.920 \pm 0.700$ & $0.043 \pm 0.015$ \\
& $\mathrm{Ni}$ & $1.721 \pm 0.051$ & $1.219 \pm 0.005$ & $1.228 \pm 0.000$ & $0.918 \pm 0.00$ & $2.8467 \pm 0.231$ & $0.723 \pm 0.011$ \\
& $\mathrm{~Pb}$ & $10.529 \pm 0.027$ & $2.202 \pm 0.001$ & $8.713 \pm 0.051$ & $18.065 \pm 0.00$ & $20.42 \pm 0.100$ & $2.802 \pm 0.023$ \\
\hline
\end{tabular}

Key: CSK Cabbage Soil Kano, LSK Lettuce Soil Kano, OSK Okra Soil Kano, WSK Watermelon Soil Kano, SSK Spinach Soil Kano, PSK Pepper Soil Kano. ND Not Detectible 
Table 2 Mean Concentration of Heavy Metals in Kano Vegetables Leaves

\begin{tabular}{llllllll}
\hline Area & Metals & CLK & LLK & OLK & WLK & $\begin{array}{l}\text { SLK } \\
\text { Mean } \pm \text { SD }\end{array}$ & $\begin{array}{l}\text { PLK } \\
\text { Mean } \pm \text { SD }\end{array}$ \\
\hline Kano & $\mathrm{Cd}$ & $0.009 \pm 0.00$ & $0.018 \pm 0.001$ & $0.063 \pm 0.001$ & $0.007 \pm 0.001$ & $0.027 \pm 0.001$ & $0.022 \pm 0.001$ \\
& $\mathrm{Co}$ & $\mathrm{ND}$ & $0.133 \pm 0.003$ & ND & ND & ND & ND \\
& $\mathrm{Cr}$ & $0.126 \pm 0.005$ & $0.063 \pm 0.003$ & $0.353 \pm 0.025$ & $0.140 \pm 0.010$ & $0.002 \pm 0.001$ & $0.010 \pm 0.00$ \\
& $\mathrm{Mn}$ & $15.250 \pm 0.051$ & $11.304 \pm 0.001$ & $7.957 \pm 0.058$ & $4.550 \pm 0.045$ & $2.751 \pm 0.000$ & $2.206 \pm 0.002$ \\
& $\mathrm{Ni}$ & $2.591 \pm 0.010$ & $3.544 \pm 0.001$ & $3.361 \pm 0.048$ & $5.161 \pm 0.002$ & $2.152 \pm 0.000$ & $0.423 \pm 0.002$ \\
& $\mathrm{~Pb}$ & $10.081 \pm 0.001$ & $7.975 \pm 0.032$ & $9.153 \pm 0.051$ & $13.723 \pm 0.552$ & $9.238 \pm 0.100$ & $2.478 \pm 0.051$ \\
\hline
\end{tabular}

Key: CLK Cabbage Leaves Kano, LLK Lettuce Leaves Kano, OLK Okra Leaves Kano, WLK Watermelon Leaves Kano SLK Spinach Leaves Kano, PLK Pepper Leaves Kano. ND Not Detectible

Table 3 Mean Concentration of Heavy Metals of Bichi Soils

\begin{tabular}{|c|c|c|c|c|c|c|c|}
\hline Area & $\begin{array}{l}\text { Metals } \\
\mathrm{mg} / \mathrm{Kg}\end{array}$ & $\begin{array}{l}\text { CSB } \\
\text { Mean } \pm S D\end{array}$ & $\begin{array}{l}\text { LSB } \\
\text { Mean } \pm \text { SD }\end{array}$ & $\begin{array}{l}\text { OSB } \\
\text { Mean } \pm \text { SD }\end{array}$ & $\begin{array}{l}\text { WSB } \\
\text { Mean } \pm S D\end{array}$ & $\begin{array}{l}\text { SSB } \\
\text { Mean } \pm S D\end{array}$ & $\begin{array}{l}\text { PSB } \\
\text { Mean } \pm \text { SD }\end{array}$ \\
\hline \multirow[t]{6}{*}{ Bichi } & $\mathrm{Cd}$ & ND & ND & ND & ND & ND & ND \\
\hline & Co & ND & $1.095 \pm 0.005$ & ND & $1.485 \pm 0.001$ & ND & ND \\
\hline & $\mathrm{Cr}$ & $0.042 \pm 0.040$ & $0.083 \pm 0.005$ & $0.070 \pm 0.010$ & $0.01 \pm 0.00$ & $0.067 \pm 0.020$ & $0.020 \pm 0.010$ \\
\hline & $\mathrm{Mn}$ & $19.450 \pm 0.017$ & $20.161 \pm 0.003$ & $12.066 \pm 0.002$ & $25.00 \pm 0.000$ & $22.023 \pm 0.000$ & ND \\
\hline & $\mathrm{Ni}$ & $2.557 \pm 0.049$ & $3.189 \pm 0.002$ & $6.542 \pm 0.038$ & $1.234 \pm 0.000$ & $1.424 \pm 0.010$ & $1.546 \pm 0.056$ \\
\hline & $\mathrm{Pb}$ & $5.355 \pm 0.019$ & $1.413 \pm 0.001$ & $2.291 . \pm 0.067$ & $15.570 \pm 0.005$ & $11.764 \pm 0.294$ & $2.541 \pm .0 .001$ \\
\hline
\end{tabular}

Key: CSB Cabbage Soil Bichi, LSB Lettuce Soil Bichi, OSB Okra Soil Bichi, WSB Water melon Soil Bichi, SSB Spinach Soil Bichi, PSB Pepper Soil Bichi. ND Not Detectible

Table 4 Mean Concentration of Heavy Metals of Bichi Vegetables Leaves

\begin{tabular}{|c|c|c|c|c|c|c|c|}
\hline Area & $\begin{array}{l}\text { Metals } \\
\mathrm{mg} / \mathrm{Kg}\end{array}$ & $\begin{array}{l}\text { CLB } \\
\text { Mean } \pm \text { SD }\end{array}$ & $\begin{array}{l}\text { LLB } \\
\text { Mean } \pm \text { SD }\end{array}$ & $\begin{array}{l}\text { OLB } \\
\text { Mean } \pm S D\end{array}$ & $\begin{array}{l}\text { WLB } \\
\text { Mean } \pm \text { SD }\end{array}$ & $\begin{array}{l}\text { SLB } \\
\text { Mean } \pm \text { SD }\end{array}$ & $\begin{array}{l}\text { PLB } \\
\text { Mean } \pm \text { SD }\end{array}$ \\
\hline \multirow[t]{6}{*}{ Bichi } & $\mathrm{Cd}$ & ND & ND & ND & ND & ND & ND \\
\hline & Co & ND & ND & $0.022 \pm 0.001$ & ND & ND & $0.165 \pm 0.001$ \\
\hline & $\mathrm{Cr}$ & $0.146 \pm 0.010$ & $0.130 \pm 0.010$ & $0.153 \pm 0.005$ & $0.035 \pm 0.010$ & $0.880 \pm 0.010$ & $0.360 \pm 0.000$ \\
\hline & $\mathrm{Mn}$ & $2.025 \pm 0.001$ & $11.444 \pm 0.009$ & $4.673 \pm 0.041$ & $11.072 \pm 0.019$ & $11.494 \pm 0.041$ & $0.198 \pm 0.000$ \\
\hline & $\mathrm{Ni}$ & $1.474 \pm 0.011$ & $0.991 \pm 0.004$ & $0.928 \pm 0.002$ & $1.443 . \pm 0.001$ & $2.837 \pm 0.003$ & $1.747 \pm 0.022$ \\
\hline & $\mathrm{Pb}$ & $4.050 \pm 0.006$ & $1.422 \pm 0.010$ & $1.070 \pm 0.017$ & $9.668 \pm 0.007$ & ND & $3.267 \pm 0.304$ \\
\hline
\end{tabular}

Key: CLB Cabbage Leaves Bichi, LLB Lettuce Leaves Bichi, OLB Okra Leaves Bichi, WLB Watermelon Leaves Bichi, SLB Spinach Leaves Bichi, PLB Pepper Leaves Bichi. ND Not Detected 
Table 5 World Health Organization Maximum Permissible Standard

\begin{tabular}{lll}
\hline Metals & MPL in Soils $\mathbf{~ m g / K g}$ & MPL in Vegetables $\mathbf{~ M g / K g}$ \\
\hline Cadmium & 3 & 1.00 \\
Cobalt & 50 & 0.10 \\
Chromium & 100 & 0.10 \\
Manganese & 2000 & 500 \\
Nickel & 50 & 5 \\
Lead & 100 & 0.30 \\
\hline & Adapted from Mohsen and Mohsen [19]; Chiroma et al., [20] and Toth [21]
\end{tabular}

Table 6 Significance of Pollution Indices of Heavy Metals in Vegetables of Different Farms in Kano City

\begin{tabular}{|c|c|c|c|c|c|c|}
\hline Crop & $\begin{array}{l}\mathrm{Mn} \\
\mathrm{mg} / \mathrm{Kg}\end{array}$ & $\begin{array}{l}\text { Implication of } \\
\text { Cp Index }\end{array}$ & $\begin{array}{l}\mathrm{Ni} \\
\mathrm{mg} / \mathrm{Kg}\end{array}$ & $\begin{array}{l}\text { Implication of } \mathrm{Cp} \\
\text { Index }\end{array}$ & $\begin{array}{l}\mathrm{Pb} \\
\mathrm{mg} / \mathrm{Kg}\end{array}$ & $\begin{array}{l}\text { Implication of Cp } \\
\text { Index }\end{array}$ \\
\hline Cabbage & 0.43 & $\begin{array}{l}\text { Slightly } \\
\text { contaminated }\end{array}$ & 1.50 & Slightly polluted & 0.95 & $\begin{array}{l}\text { Severely } \\
\text { contaminated }\end{array}$ \\
\hline Lettuce & 1.08 & Slightly polluted & 2.91 & $\begin{array}{l}\text { Moderately } \\
\text { polluted }\end{array}$ & 3.62 & $\begin{array}{l}\text { Moderately } \\
\text { polluted }\end{array}$ \\
\hline Okra & 2.39 & Slightly polluted & 2.69 & $\begin{array}{l}\text { Moderately } \\
\text { polluted }\end{array}$ & 1.50 & Slightly polluted \\
\hline Watermelon & 0.21 & $\begin{array}{l}\text { Moderately } \\
\text { contaminated }\end{array}$ & 5.63 & Severely polluted & 0.75 & $\begin{array}{l}\text { Severely } \\
\text { contaminated }\end{array}$ \\
\hline Spinach & 0.17 & $\begin{array}{l}\text { Slightly } \\
\text { contaminated }\end{array}$ & 0.78 & $\begin{array}{l}\text { Slightly } \\
\text { contaminated }\end{array}$ & 0.45 & $\begin{array}{l}\text { Moderately } \\
\text { contaminated }\end{array}$ \\
\hline Pepper & 0.20 & $\begin{array}{l}\text { Moderately } \\
\text { contaminated }\end{array}$ & 0.58 & $\begin{array}{l}\text { Severely } \\
\text { contaminated }\end{array}$ & 0.88 & $\begin{array}{l}\text { Very severely } \\
\text { contaminated }\end{array}$ \\
\hline
\end{tabular}

Table 7 Significance of Pollution Indices of Heavy Metals in Vegetables of Different Farms in Bichi

\begin{tabular}{|c|c|c|c|c|c|c|}
\hline Crop & $\begin{array}{l}\mathrm{Mn} \\
\mathrm{mg} / \mathrm{Kg}\end{array}$ & $\begin{array}{l}\text { Implication of } \\
\text { Cp Index }\end{array}$ & $\begin{array}{l}\mathrm{Ni} \\
\mathrm{mg} / \mathrm{Kg}\end{array}$ & $\begin{array}{l}\text { Implication of } \\
\text { Cp Index }\end{array}$ & $\begin{array}{l}\mathrm{Pb} \\
\mathrm{mg} / \mathrm{Kg}\end{array}$ & $\begin{array}{l}\text { Implication of } \\
\text { Cp Index }\end{array}$ \\
\hline Cabbage & 0.14 & $\begin{array}{l}\text { Slightly } \\
\text { contaminated }\end{array}$ & 0.57 & $\begin{array}{l}\text { Severely } \\
\text { contaminated }\end{array}$ & 0.75 & $\begin{array}{l}\text { Severely } \\
\text { contaminated }\end{array}$ \\
\hline Lettuce & 0.56 & $\begin{array}{l}\text { Severely } \\
\text { contaminated }\end{array}$ & & $\begin{array}{l}\text { Moderately } \\
\text { polluted }\end{array}$ & 1.00 & $\begin{array}{l}\text { Very severely } \\
\text { contaminated }\end{array}$ \\
\hline Okra & 0.38 & $\begin{array}{l}\text { Moderately } \\
\text { contaminated }\end{array}$ & 0.14 & Slightly polluted & 0.46 & $\begin{array}{l}\text { Moderately } \\
\text { contaminated }\end{array}$ \\
\hline Watermelon & 0.44 & $\begin{array}{l}\text { Moderately } \\
\text { contaminated }\end{array}$ & 1.16 & $\begin{array}{l}\text { Moderately } \\
\text { polluted }\end{array}$ & 0.64 & $\begin{array}{l}\text { Slightly } \\
\text { contaminated }\end{array}$ \\
\hline Spinach & 0.52 & $\begin{array}{l}\text { Severely } \\
\text { contaminated }\end{array}$ & 0.50 & $\begin{array}{l}\text { Slightly } \\
\text { contaminated }\end{array}$ & 0.00 & $\begin{array}{l}\text { Very slightly } \\
\text { contaminated }\end{array}$ \\
\hline Pepper & 0.00 & $\begin{array}{l}\text { Very slightly } \\
\text { contaminated }\end{array}$ & 1.12 & Slightly polluted & 1.88 & $\begin{array}{l}\text { Very severely } \\
\text { contaminated }\end{array}$ \\
\hline
\end{tabular}


Table 8 Significance of Intervals of Contamination/Pollution Index (CPI) standard

\begin{tabular}{ll}
\hline CPI & Significance \\
\hline$<0.1$ & Very slightly contaminated \\
$0.10-0.28$ & Slightly contaminated \\
$0.26-0.5$ & Moderately contaminated \\
$0.51-0.75$ & Severely contaminated \\
$0.76-1.00$ & Very severely contaminated \\
$1.1-2$ & Slightly polluted \\
$2.1-4$ & Moderately polluted \\
$4.1-8$ & Severely polluted \\
$8.1-16$ & Very severely polluted \\
$>16$ & Excessively polluted \\
\hline
\end{tabular}

\subsection{Cadmium}

Cadmium is a heavy metal classified as a group one carcinogen by IARC [22] affecting multiple systems in humans and animals. Exposure to cadmium occurs primarily through ingestion of contaminated water, food and to a significant extent through inhalation and cigarette smoking [23]. Cadmium has an extremely long biological half-life of 20 years, and it primarily affects the liver, intestine, and the kidneys, with prolong exposure proven to be carcinogenic to almost all body systems ranging from the kidneys, lungs, liver, to prostate and hematopoietic systems [24]. Cadmium is a bioavailable and very mobile metal that easily accumulates in crops and humans [13, 25]. The highest mean cadmium concentration in soils analyzed in this study was obtained from okro soil of Kano City was found to be $0.014 \pm 0.001$ $\mathrm{mg} / \mathrm{Kg}$, with the lowest concentration of $0.001 \pm 0.001 \mathrm{mg} / \mathrm{Kg}$ equally obtained in the lettuce soil of Kano City, while all the Bichi soil samples reported none detectable cadmium concentrations. Similarly, the highest concentration of cadmium in vegetables was obtained from the Kano City samples, with the okro leaves recording a mean cadmium concentration of $0.063 \pm 0.001 \mathrm{mg} / \mathrm{Kg}$, with the lowest concentration of $0.007 \pm 0.001 \mathrm{mg} / \mathrm{Kg}$ equally obtained in watermelon leaves of Kano, while all the Bichi vegetable samples reported none detectable cadmium concentrations. All the concentrations of cadmium obtained from this study are below the WHO maximum permissible standard of 0.10 $\mathrm{mg} / \mathrm{Kg}$. Also the results from this study are in agreement with similar results reported by Salawu et al., [26] who reported a concentration of $0.022 \pm 0.0014 \mathrm{mg} / \mathrm{Kg}$ for cadmium in spinach, and Mohammad and Folorunsho [27] who reported a concentration of $0.018-8.02 \mathrm{mg} / \mathrm{Kg}$. However, the results from this study are lower than that reported by Adeel and Riffa [28] who reported a higher cadmium concentration of $1.29-5.18 \mathrm{mg} / \mathrm{Kg}$ in spinach. The findings are below that reported by Nafiu and Aisha [15] who reported a range of 0.35 to $0.59 \mathrm{mg} / \mathrm{Kg}$ in three West African cities including Kano. The variation of this current research and that of the previous works may be due to soil types, soil depth and effluents discharge [27]. Bichi soils and vegetables that recorded no cadmium concentration may be attributed to zero atmospheric deposit of cadmium in the sample area, with the sample area found to experience less anthropogenic activities [19].

\subsection{Cobalt}

Cobalt is an element which is essential to human health (e.g. it is part of vitamin B), but which in excess amounts can cause serious effects to lungs and heart [29]. Cobalt presence was detected only in Kano lettuce soil and leaves, $0.322 \pm 0.049$ and $0.133 \mathrm{mg} / \mathrm{Kg}$ respectively. This result is far below World Health Organization maximum permissible level of cobalt $50 \mathrm{mg} / \mathrm{Kg}$ Table 5 and European union (EU) $100 \mathrm{mg} / \mathrm{Kg}$, this is as well lower than findings of Adeel and Riffa [28] who reported a range of 4.28 to $33.39 \mathrm{mg} / \mathrm{Kg}$, and Babandi et al., [13] reported lower concentration of cobalt in agricultural soil $19 \mu \mathrm{g} / \mathrm{g}$. The recommended permissible level of cobalt in vegetable by world health organization in soils is $0.1 \mathrm{mg} / \mathrm{Kg}$. Concentration of cobalt were also obtained in this current study in Kano vegetables spinach and pepper leaves $0.027 \pm 0.001$ and $0.022 \pm 0.001 \mathrm{mg} / \mathrm{Kg}$, all the findings are far below the World Health Organization permissible limit, but the findings are in agreement with report by Abdulmojeed and Abdulrahman [30] who recorded cobalt concentration in spinach between $0.24 \pm 0.09$ to $0.73 \pm 0.06 \mathrm{mg} / \mathrm{Kg}$ range and in okra between $0.24 \pm 0.16$ to $0.97 \pm 0.81$ range. The uptake of cobalt (Co) by plants varies with plant species. Other researches like Babandi et al., [13] in their study reported cobalt in lettuce $7.00 \pm 4.00 \mu \mathrm{g} / \mathrm{g}$ and $13.00 \pm 8.00 \mu \mathrm{g} / \mathrm{g}$, carrot leaves $8.00 \pm 4.00 \mu \mathrm{g} / \mathrm{g}$. On the other 
hand, Mohsen and Mohsen [19] reported cobalt concentration of $3.04 \mathrm{mg} / \mathrm{Kg}$ in reddish-leaf, higher than this current research. Bichi soil and vegetables samples did not record any trace of cobalt. This may not be unconnected with zero anthropogenic activities around Bichi sampled area, this also in agreement with Mohsen and Mohsen [19] who record no cobalt no $(0.00 \mathrm{mg} / \mathrm{Kg})$ in red pepper.

\subsection{Chromium}

Chromium (Cr) is the $7^{\text {th }}$ most abundant element on the earth [31]. It is a trace mineral required by human health, due to its involvement in the synthesis of fatty acids and cholesterols, metabolism of carbohydrates, proteins, lipids and with role to facilitate the action of insulin [32, 33, 34] its ability to regulate glucose, preventing hyperglycemia or diabetes [35]. Chromium occurs in nature in bound forms that constitute $0.1-0.3 \mathrm{mg} / \mathrm{kg}$ of the earth's crust [36]. The highest mean chromium concentration in soils analyzed in this study was obtained from lettuce soil of Bichi was found to be $0.083 \pm 0.005 \mathrm{mg} / \mathrm{Kg}$, with the lowest concentration of $0.01 \pm 0.000 \mathrm{mg} / \mathrm{Kg}$ equally obtained in the watermelon soil of Bichi, while the lettuce, spinach and pepper soil samples of Kano City all reported none detectable chromium concentrations. Also, the highest concentration of chromium in vegetables was obtained from the Bichi samples, with the spinach leaves recording a mean chromium concentration of $0.880 \pm 0.010 \mathrm{mg} / \mathrm{Kg}$, with the lowest concentration of $0.010 \pm 0.00 \mathrm{mg} / \mathrm{Kg}$ obtained in pepper leaves of Kano City. The Bichi spinach leaf that recorded the highest mean chromium concentration is thus not suitable for human consumption since the concentration is far above the WHO maximum permissible limit. However, it can thus be suggested that spinach could be used in phytoremediation of chromium, with similar suggestion initially made by Hossein et al., [37]. All other concentrations of chromium obtained from this study are within or below the WHO maximum permissible standard of $0.10 \mathrm{mg} / \mathrm{Kg}$. The concentrations of chromium in vegetables in the current study were lower than that reported by Babandi et al., [13]; Mohammad and Folorunsho [27] and Mohammed and Sharif [38] who respectively reported 99.00 $112.00 \mu \mathrm{g} / \mathrm{g}, 21.35$ to $35.50 \mathrm{mg} / \mathrm{Kg}$ and 4.9 to $13.0 \mathrm{mg} / \mathrm{Kg}$ for similar vegetable leaves. The highest means concentration chromium in soil $(0.083 \pm 0.00$ $\mathrm{mg} / \mathrm{Kg})$ was found in lettuce soil of Bichi, with the lowest chromium concentration $(0.01 \pm 0.00 \mathrm{mg} / \mathrm{Kg}) \mathrm{found}$ in watermelon soil of Bichi. The findings on this study are in agreement with that reported by Abdulmojeed and Abdulrahman [30] who reported some varying concentrations in different vegetables within Kano (spinach $0.85 \pm 0.15$ $0.19 \pm 0.03$, okra $0.18 \pm 0.03-0.74 \pm 0.07$, and tomatoes $0.16 \pm 0.05-0.58 \pm 0.03 \mathrm{mg} / \mathrm{Kg}$ ). The variation in the concentrations of chromium between the sampling sites might be attributed to changes in the redox conditions and other chemical properties of the soil as a result of flooding during irrigation and modification of the soil $\mathrm{pH}$, which might have helped in changing the oxidation state of $\mathrm{Cr}$ in the cultivated soil from the stable $\mathrm{Cr}$ (III) to the highly mobile $\mathrm{Cr}$ (VI) leading to a low residual concentration of this metal [39]. Binding to dissolved organic matter could also be responsible for low $\mathrm{Cr}$ concentration in the cultivated soil [39].

\subsection{Manganese}

Manganese, a naturally occurring element, is an essential nutrient for both animal and plants that comprises of approximately $0.1 \%$ of the Earth's crust, and is the twelfth most abundant element and the fifth most abundant metal [40]. As an essential nutrient, several enzyme systems have been reported to interact with or depend on manganese for their catalytic or regulatory function [41]. Human beings are exposed to manganese through consumption of food and water, inhalation of air, and dermal contact with air, water, soil, and consumer products that contain manganese [42], with the dietary source being the primary source of manganese intake. Although low levels of manganese intake are necessary for human health, exposure to high manganese level is highly toxic, with its toxicity resulting in a permanent neurological disorder known as manganism with symptoms that include laboured movement, facial muscle spasms and tremors [43, 44, 45]. These symptoms are often preceded by other lesser symptoms, including irritability, aggressiveness, and hallucinations [45]. Concentrations of manganese in both Kano City and Bichi soils vary considerably, with both the highest and lowest mean concentrations of $34.746 \pm 0.011$ and $0.043 \pm 0.015$ respectively coming from Kano soils (cabbage and pepper). However, all the Bichi soil samples recorded high mean values of manganese ranging from $12.066 \pm 0.002$ to $25.00 \pm 0.000 \mathrm{mg} / \mathrm{Kg}$. But all these results (Kano City and Bichi samples) are far below World Health Organization threshold level of manganese in agricultural soils (2000 mg/Kg). The current findings are found to agree with similar findings by Adeel and Riffa [28] who reported a range between 20.48 to 64.19 $\mathrm{mg} / \mathrm{Kg}$ for manganese in some agricultural soil samples. All the vegetable samples analyzed in this study recorded significant amount of manganese, all of which are, however, far below the WHO maximum permissible limit. The highest recorded concentration of manganese, $15.250 \pm 0.051 \mathrm{mg} / \mathrm{Kg}$, was found in cabbage leaves Kano, while the lowest, $0.198 \pm 0.000 \mathrm{mg} / \mathrm{Kg}$, was obtained in the pepper leaves of Bichi. The findings of this study are lower than the mean concentration of manganese reported by Mohsen and Mohsen [19] who reported a mean concentration of 284.75 $\mathrm{mg} / \mathrm{Kg}$; and that reported by Chiroma et al., [20] who reported a concentration of 512 to $561 \mathrm{mg} / \mathrm{Kg}$ for lettuce leaves. However, the present study falls within the range of concentrations reported by Mohammed and Sharif [38]; Kostova et al., [46]; and Umar et al., [47]. Variation in the manganese concentrations between vegetables might be due to 
MG Doka et al. / World Journal of Advanced Research and Reviews, 2020, 07(02), 063-074

application of chemical fertilizers and pesticides, as well as soil type [47, 48, 49]. Comparing the contamination pollution index (Cp) of the two sample sites indicated Kano vegetable are more polluted with manganese than Bichi vegetables.

\subsection{Nickel (Ni)}

Nickel has been considered to be an essential trace element for human and animal health [50], and occurs in the environment only at very low levels and is essential in small doses, but it can be harzardous at extremely high doses [51]. Exposure to large quantities of nickel may be highly carcinogenic, resulting in the cancer of the lungs, nose, larynx and prostate [50]. Exposure to nickel has also been reported to cause birth defect, respiratory failure, lung embolism, asthma and chronic bronchitis [50]. Nickel is unique among plant nutrients because it functions in plant growth and development [52]. Availability of nickel in soil arises from both natural and man-made sources, with man-made source of nickel including sludge and fertilizer applications, metal refining, burning of coal, burning of petroleum products, disposal of waste sewage, metal plating, nickel mining and electroplating, as well as combustion of fossil fuels [53, 54, 55]. Nickel in the present study shows a diversifying results in the two sampling location, Kano vegetable generally shows higher concentrations (2.591 \pm 0.010 and $5.161 \pm 0.002 \mathrm{mg} / \mathrm{Kg}$ ) compared to Bichi. High mean levels of nickel in Kano vegetables might be attributed to industrial discharges and emissions [56]. However, all the present findings are way below permissible limit set by World Health Organization of $5.0 \mathrm{mg} / \mathrm{Kg}$, and in agreement with that reported by Abdulmojeed and Abdulrahman [30] in spinach $(2.02 \pm 0.35 \mathrm{mg} / \mathrm{Kg}$ to $1.39 \pm 0.10 \mathrm{mg} / \mathrm{Kg}) ;$ okra $(0.08 \pm 0.06$ to $1.13 \pm 0.01$ $\mathrm{mg} / \mathrm{Kg}$ ). Similarly, the present study agree with similar result from Sawidis et al., [57]; Sharma et al., [58]; Elbagermi et al., [59]; Guerra et al., [60]. Mohsen and Mohsen [19] reported nickel concentrations (20.52 mg/Kg) far above what has been reported in this study. For concentrations of nickel in the soil samples, both Kano and Bichi recorded nickel between the ranges $0.918 \pm 0.005$ watermelon soil Kano to $2.8467 \pm 0.389 \mathrm{mg} / \mathrm{Kg}$ of spinach soil Kano. These results are in agreement with the range of results $(0.150$ to $1.031 \mathrm{mg} / \mathrm{Kg})$ reported by Ruqia et al., [4]. These results are below permissible limit set by World Health Organization for agricultural soil and European commission (EU) $50 \mathrm{mg} / \mathrm{Kg}$ and 75. $\mathrm{mg} / \mathrm{Kg}$ respectively. Contamination pollution index of all the sampled soil vegetables indicated Kano vegetables are more polluted with nickel than those of Bichi as result of atmospheric deposition as positive factor that increase concentration by transpiration.

\subsection{Lead (Pb)}

Lead is a naturally occurring toxic metal found in the Earth's crust. Its widespread use has resulted in extensive environmental contamination, human exposure and significant public health problems in many parts of the world [61]. Food is one of the major sources of lead exposure, with air (mainly lead dust originating from petrol) and drinking water being the other sources [62]. Plants may be contaminated with lead through its uptake from ambient air and soil, and animals may then ingest the lead contaminated vegetation. In humans, lead ingestion may arise from eating lead contaminated vegetation or animal foods [63]. In this study the highest mean concentration of lead in soil was found in Kano spinach soil $(20.420 \pm 0.010 \mathrm{mg} / \mathrm{Kg}$, while the lowest occurred in lettuce soil Bichi $(1.413 \pm 0.001 \mathrm{mg} / \mathrm{Kg}), \mathrm{with}$ all these values below the World Health Organization recommended level for agricultural soil of $100 \mathrm{mg} / \mathrm{Kg}$. These values are in agreement with 1.7 to $16.5 \mathrm{mg} / \mathrm{Kg}$ range reported by Mohammed and Sharif [38], and 8.38 to $21.40 \mathrm{mg} / \mathrm{Kg}$ range reported by Adeel and Riffa [28]. Comparatively, concentrations of lead in this study indicated higher levels of lead in Kano vegetables than those obtained from Bichi vegetables. The highest mean lead concentration in the analyzed vegetables $(13.723 \pm 0.552)$ was found in watermelon leaf of Kano. However, it is worthy of notice that watermelon leaves are note typically consumed in Kano and its environs. This result is far above $0.87-1.41 \mathrm{mg} / \mathrm{Kg}$ values reported by Mohammad and Folorunsho [27] and $28.00 \pm 2.00 \mathrm{mg} / \mathrm{Kg}$ reported by Babandi et al., [13]. Lead concentration in the current study indicates that the levels of concentration are found to be above World Health Organization permissible level of $0.30 \mathrm{mg} / \mathrm{Kg}$. Other researcher who reported mean lead concentrations in vegetables higher than the World Health Organization permissible levels include Abdulmojeed and Abdulrahman [30] who recorded lead concentration in spinach around Kano in the range of $0.97 \pm 0.05$ to $1.60 \pm 0.93 \mathrm{mg} / \mathrm{Kg}$ and $0.71 \pm 0.04$ to $1.10 \pm 0.04$ for okro. Similarly, Salawu et al., [26] reported mean lead concentration of 0.613 $\pm 0.0009 \mathrm{mg} / \mathrm{Kg}$; Mohsen and Mohsen [19] reported 2.57 $\mathrm{mg} / \mathrm{Kg}$ in spinach; Babandi et al., [13] reported $15.00 \pm 8.00 \mathrm{mg} / \mathrm{Kg}$ in lettuce, and $10.21 \pm 0.20 \mathrm{mg} / \mathrm{Kg}$ in okro. Comparing the contamination pollution index ( $\mathrm{Cp}$ ) of the two sampled sites, Kano City vegetables are more polluted with lead than Bichi vegetables. Apart from atmospheric deposit of lead, lead concentration may be increased as result of large amount of waste containing lead presence in the environment. The toxicity of lead is well documented in literature, being a zootoxic metal, needs to be monitored in plant parts used by humans and animals [25]. Additionally, since $\mathrm{Pb}^{2+}$ is not biodegradable, once soil has become contaminated with it, it remains a long-term source of Pb exposure [64].

Using the criteria of Lacatusu [11] in Tables 6 and 7, the vegetables from the different farms in Kano are excessively polluted $(\mathrm{C} / \mathrm{P}>16)$ with the three selected heavy metals $\mathrm{Ni}, \mathrm{Mn}$ and $\mathrm{Pb}$. The vegetables in Bichi are only slightly less contaminated. By the Lacatusu criteria [11], this implies that the urban drainage waters are not safe for vegetable irrigation. This is of very serious concern since the irrigated crops are consumed together with absorbed heavy metals 
and thus find their way up the human food chain where they can be very poisonous to consumers. Some of the vegetable may be very dangerous in consideration of their ability to contain heavy metals in large concentrations.

\section{Conclusion}

Continuous using of untreated wastewater for irrigation for the urban farming has caused an ample buildup of toxic metals contamination in soils and plants, which subsequently bio accumulate in human body causing very dangerous diseases. Hence this necessitates the need for regular monitoring of such urban vegetables to curtail human health risks associated with their consumptions. This study reported the concentrations of some potentially toxic elements in six commonly consumed vegetables in Kano City and Bichi town. The results showed that the concentrations of some of the elements are above the permissible limit recommended by World Health Organization, thus should not be recommended for human consumption.

\section{Compliance with ethical standards}

\section{Acknowledgments}

The authors are grateful to the Tertiary Education Trust Fund (Tet-Fund) for sponsoring this research. Also we wish to acknowledge the chairman and members of research seminar and publication committee, Federal Collage of Education (Technical) Bichi, Kano and the entire management of Federal Collage of Education (Technical) Bichi. In addition we wish to appreciate support given by personnel of Soil Science laboratory, Bayero University Kano.

\section{Disclosure of conflict of interest}

The authors have no any conflict of interest to report.

\section{References}

[1] Idakwoji PA. (2016). Assessment of Heavy Metal Contamination of Soil and Cassava Plants within the Vicinity of a Cement Factory in North Central, Nigeria. Advances in Applied Science Research, 7(3), 20-27.

[2] Javid MM, Manoj S and Khursheed AW. (2018). Heavy Metals in Vegetable and their Impact on the Nutrient Quality of Vegetables: A Review, Journal of Plant Nutrition, 41(13), 1744-1763.

[3] Reena S, Neetu G, Anurag M and Rajiv G. (2011). Heavy Metals and Living Systems: An Overview, Indian Journal of Pharmacology, 43(3), 246-253.

[4] Ruqia N, Muslim K, Muhammad M, Hameed R, Naveed R, Surrya S, Nosheen A, Muhammad S, Mohib U, Muhammad $\mathrm{R}$ and Zeenat S. (2015). Accumulation of Heavy Metals (Ni, Cu, Cd, Cr, Pb, Zn, Fe) in the Soil, Water and Plants and Analysis of Physico-Chemical Parameters of Soil and Water Collected from Tanda Dam Kohat. Journal of Pharmaceutical Sciences and Research, 7(3), 89-97.

[5] Abdola M and Chmtelnicka J. (1990). New Aspects on the Distribution and Metabolism of Essential Trace Elements after Dietary Exposure to Toxic Metals, Biological Trace Element Research, 23, 25-53.

[6] Thompson HC and Kelly WC. (2003). Vegetable Crops. 5th Edn. New Delhi: McGraw Hill Publishing Company Ltd, 199067.

[7] Damek-Poprawa M and Sawicka-Kapusta K. (2003). Damage to Liver, Kidney and Teats with Reference to Burden of Heavy Metals in Yellow-Necked Mice from Areas around Steelworks and Zinc Smelters in Poland, Toxicological Journal, 186(1-2), 147-158.

[8] Brigdeli M and Seilsepour M. (2008). Investigation of Metals Accumulation in some Vegetables Irrigated with Wastewater in Shahre Rey-Iran and Toxicological Implications, American-Eurasian Journal of Agricultural and Environmental Sciences, 4(1), 86-92.

[9] Ewers U. (1991). Standards, Guidelines and Legislative Regulations Concerning Metals and their Compounds. In: Metals and their Compounds in the Environment, Merian E (Ed). VCH, Weinheim, New York, Basel, Cambridge, 687-711.

[10] Kabata-Pendias A. (1995). Agricultural Problems Related to Excessive Trace Metal Contents of Soil: In: Heavy Metals (Problems and Solutions), Salomons W., U Forstner and P. Mader (Eds). Springer-Verlag, New York USA, 3-18. 
[11] Lacatusu R. (1998). Appraising Levels of Soil Contamination and Pollution with Heavy Metals. In-Land Information System for Planning the Sustainable Use of Land Resources. HJW. Heinike, AJ. Eckelma, RJA. Thomasson, LM. Jones and B. Buckley (Eds). European Soil Bureau, Research Report No 4, Office for Official Publication of the European Communities, Luxembourg, 393-402.

[12] Ekwue YA, Gbadebo AM, Arowolo TA and Adesodun JK. (2012). Assessment of Metal Contamination in Soil and Plants from Abandoned Secondary and Primary Goldmines in Osun State, Nigeria, Journal of Soil Science and Environmental Management, 3(11), 262-274.

[13] Babandi A, Atiku MK, Alhassan AJ, Ibrahim A and Shehu D. (2012). Level of Heavy Metals in Soil and some Vegetables Irrigated with Industrial Wastewater around Sharada Industrial Area, Kano, Nigeria. Chemsearch Journal, 3(2), 34-38.

[14] Emmanuel B and Nuruddeen A. (2012). Physicochemical Analysis of Groundwater Samples of Bichi Local Government Area of Kano State of Nigeria. World Environment, 2(6), 116-119.

[15] Nafiu A and Aisha A. (2010). Vertical Distribution of Heavy Metals in Wastewater Irrigated Vegetable Garden Soils of Three West African Cities. Natural cycle agroecosystem, 89, 387-397.

[16] AOAC. (1984). Official Methods of Analysis. 14th Edition, Association of Analytical Chemists, Washington DC, 249252.

[17] Okalebo JR and Gathua KW. (1993). Laboratory Methods of Soil and Plant Analysis. Kenya; marvel EPZ, 11-63.

[18] Anthony GK and Balwnt S. (2006). Heavy Metals Contamination in Vegetables Grown in Urban and Metal Smelter Contaminated Sites in Australia. Water, Air and Soil Pollution, 169, 101-123.

[19] Mohsen B and Mohsen SR. (2008). Investigation of Metals Accumulation in Some Vegetables Irrigated with Wastewater in Shahre Rey-Iran and Toxicological Implications, American-Eurasian Journal of Agriculture and Environmental Science, 4(1), 86-92.

[20] Chiroma TM, Ebewele RO and Hymore FK. (2014). Comparative Assessment of Heavy Metal Levels in Soil, Vegetables and Urban Grey Waste Water Used for Irrigation in Yola and Kano. International Refereed Journal of Engineering and Science (IRJES), 3(2), 01-09.

[21] Toth G, Hermann T, Da-Silva MR and Montanarella L. (2016). Heavy metals in Agricultural Soils of the European Union with Implications for Food Safety. Environmental International, 88, 299-309.

[22] IARC. (1994). IARC Monographs on the Evaluation of Carcinogenic Risks to Humans, Vol. 60, Some Industrial Chemicals, Lyon, IARC Press, 321-346.

[23] Giuseppe G, Maria SS, Graziantonio L, Alessia C and Alessia C. (2020). The Effects of Cadmium Toxicity, International Journal of Environmental Research and Public Health, 17(11), 3782.

[24] Angshuman S, Geethanjali R and Vishnuvardhan K. (2013). A Brief Review on the Effect of Cadmium Toxicity: From Cellular to Organ Level, International Journal of Bio-Technology and Research (IJBTR), 3(1), 17-36.

[25] Alloway BJ. (1995). Soil Processes and the Behavior of Metals. In:Alloway BJ. (Ed), Heavy Metals in Soils London: Blackie, 38-57.

[26] Salawu K, Barau MM, Mohammed D, Mikailu DA, Abdullahi BH and Uroko RI. (2015). Determination of some Selected Heavy Metals in Spinach and Irrigated Water from Samaru Area within Gusau Metropolis in Zamfara State, Nigeria. Journal of Toxicology and Environmental Health Science, 7(8), 78-80.

[27] Mohammed SA and Folorunsho JO. (2015). Heavy Metals Concentration in Soil and Amaranthus retroflexus Grown on Irrigated Farmlands in the Makera Area, Kaduna, Nigeria. Journal of Geography and Regional Planning, 8(8), 210-217.

[28] Adeel M and Riffat NM. (2014). Human Health Risk Assessment of Heavy Metals Via Consumption of Contaminated Vegetables Collected from Different Irrigation Sources in Lahore, Pakistan. Arabian Journal of Chemistry, 7, 91-99.

[29] ATSDR. (2004). United States Agency for Toxic Substances and Disease Registry. Toxicological Profile for Cobalt U.S. Department of Health and Human Services, 486.

[30] Abdulmojeed OL and Abdulrahman AA. (2011). Analysis of Heavy Metals found in Vegetables from some Cultivated Irrigated Gardens in the Kano Metropolis, Nigeria. Journal of Environmental Chemistry and Ecotoxicology, 3(6), 142-148. 
[31] Badal KM, Raviraj V and Uday KL. (2011). Speciation of Chromium in Soil and Sludge in the Surrounding Tannery Region, Ranipet, Tamil Nadu, International Scholarly Research Network, 1-10.

[32] Hummel M, Standl E and Schnell O. (2007). Chromium in Metabolic and Cardiovascular Disease, Hormone and Metabolic Research, 39(10), 743-751.

[33] Maleki A and Zarasvand MA. (2008). Heavy Metals in Selected Edible Vegetables and Estimation of their Daily Intake in Sanandaj, Iran, South East Asian, Journal of Tropical Medicine and Public Health, 39, 335-340.

[34] Despina-Maria B. (2012). Chromium Levels in Soils and Vegetables from Timis County Romania, Journal of Horticulture, Forestry and Biotechnology, 16(2), 106-111.

[35] Balk EM, Tatsioni A, Lichenstein AH, Lau J and Pittas AG. (2007). Effect of Chromium Supplementation on Glucose Metabolism and Lipids: A Systematic Review of Randomized Controlled Trials, Diabetes Care, 30(8), $2154-2163$.

[36] Jinhua Z, Min W, Wusheng J and Donghua L. (2006). Chromium Accumulation and its Effects on other Mineral Elements in Amaranthus viridis L., ACTA Biologica Cracoviensia, Series Botanica, 48(1), 7-12.

[37] Hossein F, Hamidi A, Ramlah MT and Amin M. (2014). Optimization of Phytoremediation of Lead-Contaminated Soil by Spinach (Spinacia oleracea L), International Journal of Scientific Research in Knowledge, 2(10), 480-486.

[38] Mohammed MI and Sharif N. (2011). Mineral Composition of Some Leafy Vegetables Consumed in Kano, Nigeria. Nigerian Journal of Basic and Applied Science, 19(2), 208-212.

[39] Nafiu A. (2010). Availability, Transfer and Balances of Heavy Metals in Urban Agriculture of West Africa, Volkswagen Stiftung, Kassel University Press, 31.

[40] Rollin HB. (2011). Manganese: Environmental Pollution and Health Effects, Elsevier B.V., 617-629.

[41] David S. (1997). Toxicological Profile for Manganese: Draft, Agency for Toxic Substances and Disease Registry, 1600 Clifton Road, NE, E-29, Atlanta Georgia, 65.

[42] Creina S, Angelika P, Rena K, Pierre-Louis T, Patrizia R, Nuria GT, Pierre S, Caroline D and Marcia M. (2018). Manganese in Vitivinicultural Products: Origin, Influence, Toxicity, OIV publications, $1^{\text {st }}$ Edition, Paris-France, 716.

[43] Davis JM. (1998). Methylcyclopentadienyl Manganese Tricarbonyl: Health Risk Uncertainties and Research Directions. Environmental Health Perspective, 106(Suppl 1), 191-201.

[44] Pal PK, Samii A and Calne DB. (1999). Manganese Neurotoxicity: A Review of Clinical Features, Imaging and Pathology. Neurotoxicology, 20(2-3), 227-238.

[45] Han J, Lee JS and Choi D. (2009). Manganese (II) Induces Chemical Hypoxia by Inhibiting HIF-Prolyl Hydroxylase: Implication in Manganese-Induced Pulmonary Inflammation. Toxicology and Applied Pharmacology, 235(3), 261-267.

[46] Kostova D, Kanazirska V and Kamburova M. (2008). A Comparative Analysis of Different Vegetable Crops for Content of Manganese and Molybdenum, Agronomy Research, 6(2), 477-488.

[47] Umar HM, Abdul W, Shafaqat A, Mujahid F, Rehan A, Hafiz MT, Usman I and Faakhir H. (2015). Determination of Lead $(\mathrm{Pb})$, Iron ( $\mathrm{Fe}$ ) and Manganese (Mn) Concentration in Sewage Water and Vegetable Leaf Samples, Journal of Microbiology, Biotechnology and Food Sciences, 4(5), 387-392.

[48] Sridhara N, Chary CT, Kamala D and Samuel SR. (2008). Assessing Risk of Heavy Metals from Consuming food Grown on Sewage Irrigated Soils and Food Chain Transfer, Ecotoxicology and Environmental Safety, 69(3), 513524.

[49] Tauqeer HM, Ali S, Farid M, Shakoor MB, Hannan F, Ahmad R and Iftikhar U. (2014). Physico-Chemical Characterization of Wastewater Discharged from Different Textile Industries and their Ranking on the Basis of Wastewater Treatment Facilities and Hygienic Conditions. Journal of Applied Science and Environmental Sanitation, 9(2), 123-128.

[50] Zaigham H, Zubair A, Khalid UK, Mazhar I, Rizwan UK and Jabar ZKK. (2012). Civic Pollution and its Effect on Water Quality of River Toi at District Kohat, NWFP, Research Journal of Environmental and Earth Sciences, 4(3), 334-339.

[51] Sreekanth TVM, Nagajyothi PC, Lee TN and Prasad KV. (2013). Occurrence, Physiological Responses and Toxicity of Nickel in Plants. International Journal of Environmental Science and Technology, 10(5), 1129-1140. 
[52] Guodong L, Simonne EH and Yuncong L. (2017). Nickel Nutrition in Plants, UFIFAS Extension, 1-6.

[53] Khodadoust AP, Reddy KR and Maturi K. (2004). Removal of Nickel and Phenanthrene from Kaolin Soil using Different Extractants, Environmental Engineering Science, 21, 691-704.

[54] Musa JJ, Mustapha HI, Bala JD, Ibrahim YY, Akos MP, Daniel ES, Oguche FM and Kuti IA. (2017). Heavy Metals in Agricultural Soils in Nigeria: A Review. Arid Zone Journal of Engineering, Technology and Environment, 13(5), 593-603.

[55] Kumari S, Ashwani C, Manoj K and Anand K. (2018). Toxicity of Cadmium and Nickel in Soil and Vegetables. International Journal of Current Microbiology and Applied Sciences, 7(10), 2341-2352.

[56] Yilmaz S and Zengin M. (2004). Monitoring Environmental Pollution in Erzurum by Chemical Analysis of Scot Pine (Pinus sylvestris L.) needles. Environment International, 29(8), 1041-1047.

[57] Sawidis T, Chettri MK, Papaionnou A Zachariadis G and Stratis J. (2001). A Study of Metal Distribution from Lignite Fuels using Trees as Biological Monitors. Ecotoxicology and Environmental Safety, 48, 27-35.

[58] Sharma RK, Agrawal M and Marshall F. (2006). Heavy Metals Contamination in Vegetables Grown in Wastewater Irrigated Areas of Varanasi, India. Bulletin on Environmental Contamination and Toxicology, 77, 312-318.

[59] Elbagermi MA, Edwards HGM and Alajtal AI. (2012). Monitoring of Heavy Metal Content in Fruits and Vegetables Collected from Production and Market Sites in the Misurata Area of Libya, International Scholarly Research Network ISRN, 1-5.

[60] Guerra F, Anderson RT, Takashi M, Nericlenes CM and Solange GC. (2012). Heavy Metals in Vegetables and Potential Risk for Human Health, Scientia Agricola, 69(1), 54-60.

[61] WHO. (2020). Factfile: GCE Nutrition and Food Science/Chemical Contamination, 4.

[62] Jacques 0. (2012). Environmental Health: Emerging Issues and Practice, InTech, Rijeka, Croatia, 228.

[63] Bhullar DS, Thind AS and Singla A. (2015). Childhood Lead Poisoning - A Review, Journal of Punjab Academy of Forensic Medicine and Toxicology, 15(1), 43-49.

[64] Tamene FD and Seyoum L. (2015). Determination of Levels of As, Cd, Cr, Hg and Pb in Soils and some Vegetables Taken from River Mojo Water Irrigated Farmland at Koka Village, Oromia State, East Ethiopia, International Journal of Sciences: Basic and Applied Research (IJSBAR), 21(2), 352-372.

\section{How to cite this article}

Mahadi GD, Nura T, Isaac A, Shamsu IA and Datti Y. (2020). Comparative analysis of potentially toxic elements in the soils and some vegetables collected from wastewater and river water irrigated areas in Kano city and Bichi town, Kano state, Nigeria. World Journal of Advanced Research and Reviews, 7(2), 63-74. 